\title{
$5+.37-73$
}

M

2. To: (Receiving Organization)

R. W. Root

Hanford Tanks Initiative

5. Proj./Prog./Dept./Div.:

Waste Management

8. Originator Renarks:

Release of document into HTI project files.
3. From: (Originating Organization) Numatec Hanford Co., Process Systems Design $\cap$

6. cog. Engr.:
D. F. Iwatate $/ / /$

4. Related EDT No.:

$$
\mathrm{N} / \mathrm{A}
$$

7. Purchase Order No.:

$N / A$

9. Equip./Component No.: $\mathrm{N} / \mathrm{A}$

10. System/Bldg./Facility: $\mathrm{N} / \mathrm{A}$

12. Major Assm. Owg. No.: $N / A$

13. Permit/Pernit Application No.: N/A

14. Required Response Date: $\mathrm{N} / \mathrm{A}$

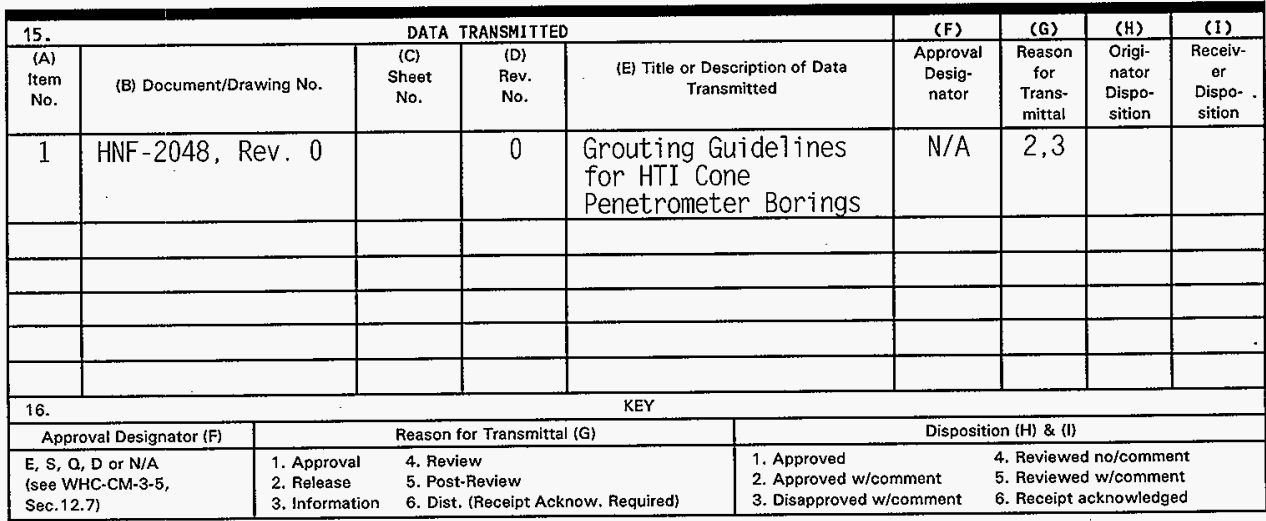

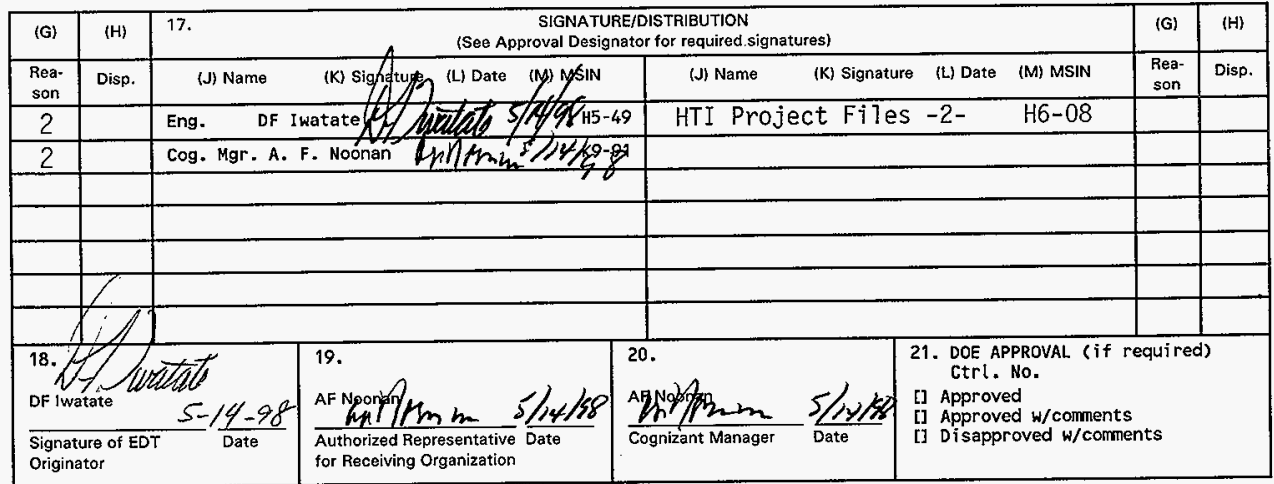


HNF-2048, Rev, 0

\section{Grouting Guidelines for Hanford Tanks Initiative Cone Penetrometer Borings}

Dr. K. Lindsay, D. B. Stephens \& Associates, Inc., Richland, WA for: $D$. F. Iwatate Numatec Hanford Company, Richland, WA 99352

U.S. Department of Energy Contract DE-AC06-96RL13200

EDT/ECN: $624527 \quad$ UC: 2030 .

Org Code: $73500 \quad$ Charge Code: D25V4

B\&R Code: EW3130010 Tota1 Pages: 2830 few

Key Words: Single-She11 Tanks, waste, plume, cone penetrometer. grouting, hole closure, vadose zone, soil

Abstract: Grouting of an open cone penetrometer (CP) borehole is done to construct a barrier that prevents the vertical migration of fluids and contaminants between geologic units and aquifers intersected by the boring. Whether to grout, the types of grout, and the method of deployment are functions of the site-specific conditions. This report recommends the strategy that should be followed both before and during HTI CP deployment to decide specific borehole grouting needs at Hanford SST farms. Topics discussed in this report that bear on this strategy include: Regulatory guidance, hydrogeologic conditions, operational factors, specific CP grouting deployment recommendations.

TRADEMARK DISCLAIMER. Reference herein to any specific commercial product, process, or service by trade name, trademark, manufacturer, or otherwise, does not necessarily constitute or imply its endorsement, recommendation, or favoring by the United States Government or any agency thereof or its contractors or subcontractors.

Printed in the United States of America. To obtain copies of this document, contact: Document Control Services, P.0. Box 950, Mailstop H6-08, Richland WA 99352, Phone (509) 372-2420; Fax (509) 376-4989.
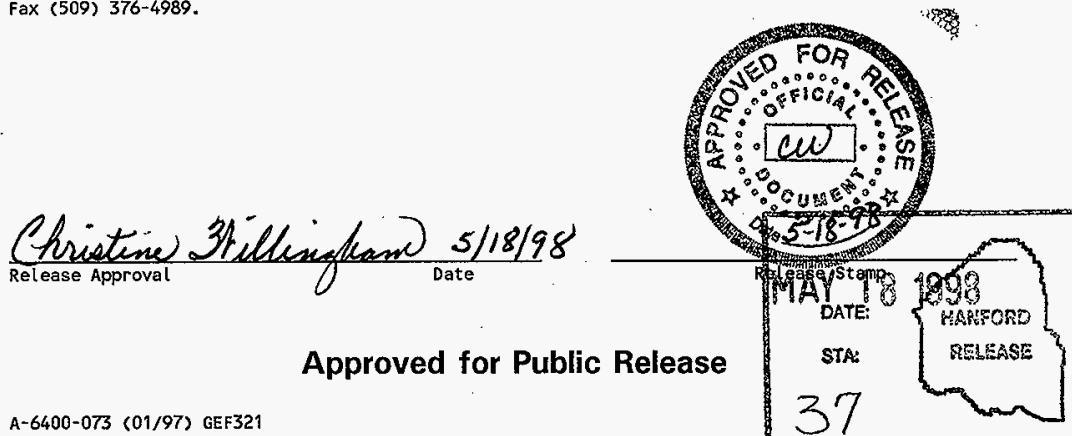
HNF-2048, Rev. 0

DANIEL B. STEPHENS \& ASSOCIATES, INC.

ENVIRONMENTAL SCIENTISTS AND ENGINEERS

\title{
Grouting Guidelines for Hanford Tank Initiative \\ Cone Penetrometer Borings
}

\author{
Prepared for \\ Waste Management Federal Services, Inc. \\ and \\ Numatec Hanford Corporation \\ Richland, Washington
}

January 2, 1998 


\section{Table of Contents}

Section

Page

1. Introduction $\ldots \ldots \ldots \ldots \ldots \ldots \ldots \ldots \ldots \ldots \ldots \ldots \ldots \ldots \ldots \ldots$

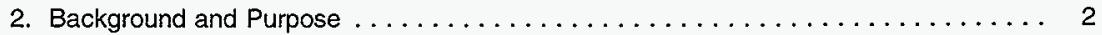

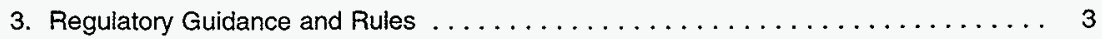

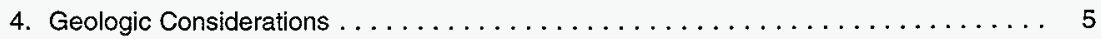

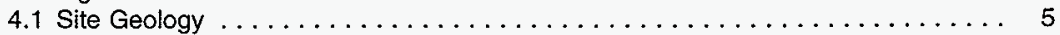

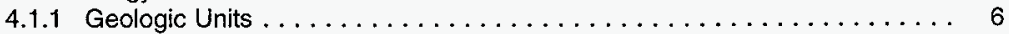

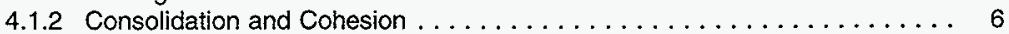

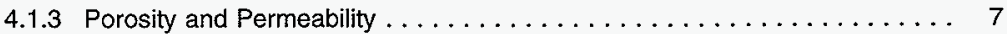

4.1 .4 Field Verification $\ldots \ldots \ldots \ldots \ldots \ldots \ldots \ldots \ldots \ldots \ldots \ldots \ldots$

4.2 Perched Water and Subsurface Moisture $\ldots \ldots \ldots \ldots \ldots \ldots \ldots$

4.3 Subsurface Contamination $\ldots \ldots \ldots \ldots \ldots \ldots \ldots \ldots \ldots \ldots \ldots$

5. Operational Considerations . . . . . . . . . . . . . . . . . . 11

5.1 Deployment . . . . . . . . . . . . . . . . . . . . . . . 11

5.2 Grout Type . . . . . . . . . . . . . . . . . . . . . . . . . 12

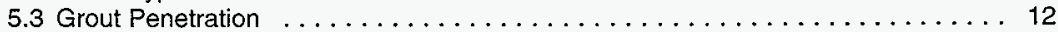

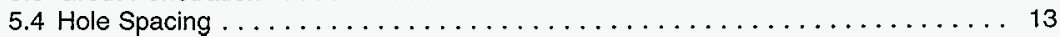

6. General Recommendations $\ldots \ldots \ldots \ldots \ldots \ldots \ldots \ldots \ldots \ldots \ldots \ldots$

7. Specific Recommendations for the $241-A X$ Tank Farm . . . . . . . . . . . . 17

7.1 Geology of the $241-A x$ Tank Farm $\ldots \ldots \ldots \ldots \ldots \ldots \ldots \ldots \ldots \ldots \ldots \ldots$

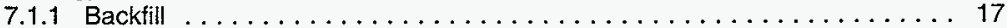

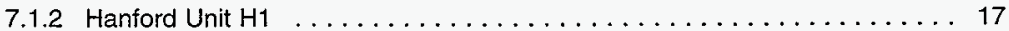

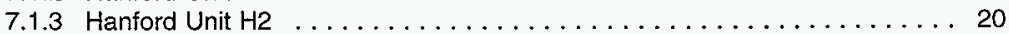

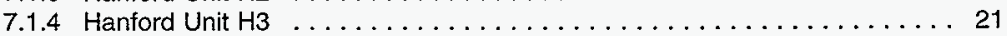

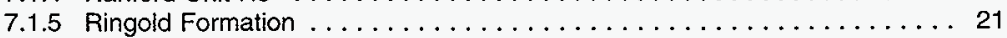

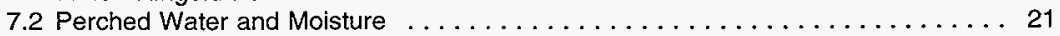

7.3 Subsurface Contamination . . . . . . . . . . . . . . . . . . 22

7.4 Deployment Recommendations for the 241 -AX Tank Farm . . . . . . . . . . . 22

References $\ldots \ldots \ldots \ldots \ldots \ldots \ldots \ldots \ldots \ldots \ldots \ldots \ldots \ldots \ldots \ldots \ldots$ 


$$
\text { HNF-2048, Rev. } 0
$$

DANIEL B. STEPHENS \& ASSOCIATES, INC.

ENVIRONMENTAL SCIENTISTS AND ENGINEERS

\section{List of Tables}

Table

Page

1 Factors That Influence Grouting Decisions .

15

\section{List of Figures}

Figure

Page

1 Flow Chart Showing Decision Tree $\ldots \ldots \ldots \ldots \ldots \ldots \ldots \ldots$

2 Generalized Geology Beneath the Hanford Site 200 Area . . . . . . . . . . 18

3 Schematic Diagram of Basic Geologic Features Beneath the 241-A and 241-AX Tank Farms. 


\section{Introduction}

The Hanford Tank Initiatives (HTI) project proposes to use the cone penotrometer $(\mathrm{CP})$ technique to emplace a large number of borings at Hanford Site single shell tank (SST) farms. These borings will be emplaced to depths of up to 150 feet below ground surface to collect data for characterizing subsurface physical conditions and to identify the location, extent, and contamination gradient of contaminant plumes in the unsaturated zone. None of the proposed CP borings will reach groundwater, which is found at depths greater than 220 feet beneath SSTs (Connelly et al., 1992a, 1992b). In addition, most, if not all, of the CP borings will be in unconsolidated and uncemented sediments (Lindsey et al., 1991, 1992, 1994b).

For fiscal year $1998 / 1999$ the HTI plume characterization project includes a task to demonstrate the capability to grout CP borings following rod extraction. Daniel B. Stephens \& Associates, inc. (DBS\&A) was contracted for the investigations, which identified a variety of factors that should be evaluated on a case-by-case basis to determine specific grouting needs for individual CP borings planned for SST farms. These factors include the following:

- Regulatory guidelines

- Site-specific hydrogeologic conditions

- Presence or absence of perched water and subsurface moisture flux

- Presence or absence of contamination

- Data acquisition objectives for individual borings

- Spacing between successive borings

Incorporating these factors into CP planning and operation will ensure that grouting is carried out where site conditions warrant, and will also allow for the most efficient use of equipment, personnel, and funding. 


\section{Background and Purpose}

CP technology (CPT) is one of several intrusive and nonintrusive techniques used for subsurface characterization (Sara, 1994). Intrusive characterization activities generally center on the emplacement of a boring using various drilling, driving, and pushing technologies. Depending on local geologic conditions, a borehole may collapse or remain open following the removal of drilling rods and casing. Open or partially collapsed boreholes can provide a pathway for fluid and contaminant migration through the subsurface by artificially connecting naturally isolated geologic units and aquifers.

Grouting of an open borehole is done to construct a barrier that prevents the vertical migration of fluids and contaminants between geologic units and aquifers intersected by the boring. Where required, grouting techniques and materials should be compatible with borehole conditions, operational considerations, and regulatory requirements. Grouting agents can consist of a variety of compounds, including portland cement, bentonite slurries, dry bentonite crumbles, and fast setting cement grouts. Grouts are placed using many methods, including tremie, pumping, and surface poring. Whether to grout, the types of grout, and the method of deployment are functions of the site-specific conditions.

This report recommends the strategy that should be followed both before and during HTI CP deployment to decide specific borehole grouting needs at Hanford SST farms. Topics discussed in this report that bear on this strategy include:

- Regulatory guidance and rules

- Hydrogeologic conditions that need to be understood prior to final borehole grouting decisions

- Operational factors that will influence grouting decisions

- Specific recommendations for CPT deployment in the 241-AX tank farm 


\section{Regulatory Guidance and Rules}

Hanford Site SST farms are in waste management areas regulated by the Washington State Department of Ecology (Ecology). Weil drilling, completion, and abandonment activities undertaken at the tank farms are regulated and guided by Ecology rules and regulations. These rules and regulations form a "bottom line" for HTl's planned CP deployment, and all activities must be carried out pursuant to them.

Chapter 173-160 of the Washington Administrative Code (WAC) defines different types of wells and borings and contains rules for their construction and abandonment. WAC 173-160-415 through 465 lists abandonment requirements for a variety of wells, all of which require grouting or sealing in one form or another. However, the planned CP borings are not considered wells because they will not penetrate to groundwater. WAC 173-160-030(47) defines a well as "any excavation that is drilled, cored, bored, washed, driven, dug, jetted, or otherwise constructed when the intended use of an excavation is for the location, diversion, artificial recharge, or withdrawal of ground water." In addition, based on the current plans and specifications for the HTI CP borings and WAC 173-160-010(3)(g), they are considered uncased geotechnical borings. Given these conditions, the planned $\mathrm{CP}$ borings simply need to be abandoned pursuant to Chapter 90.48 of the Revised Code of Washington (RCW) and WAC 173-160-010(4) in such a manner as to "ensure protection of the ground water resource and prevent contamination of that resource." This means that in situations where an abandoned $\mathrm{CP}$ boring threatens groundwater quality because it allows, or could allow, contamination of groundwater, it should be grouted.

However, given contamination conditions at Hanford, Ecology has adopted a modified position pertaining to well and boring abandonment at the site. In a letter dated February 22, 1993 from C. Cline (Ecology) to S. Wisness (U.S. Department of Energy), Ecology takes a position that at Hanford "... uncased geotechnical borings (e.g., uncased cone penotrometer holes) that penetrate below the arbitrary depth of $15 \mathrm{ft}$ shall meet the three requirements discussed above." The requirement relevant to grouting of HTI CP borings is WAC 173-160-420, which states that "Uncased wells shall be backfilled with concrete, grout, puddled clay, or high-solids bentonite." This means Ecology has taken a position that all borings at Hanford are wells (regardless of all 
other definitions). Consequently, without obtaining a variance to this position, HTI must abandon the planned CP borings pursuant to WAC-173-160-420.

Successful acquisition of a variance for the planned CP borings will rely on HTl's ability to demonstrate that proposed abandonment decisions are technically defensible and will, as required by 90.48 RCW and WAC 173-160-010(4), "ensure protection of the ground water resource and prevent contamination of that resource." This demonstration requires the collection, both before and during deployment, of data that can be used to make a technically defensible grouting decision. The remainder of this report examines the technical issues that should be addressed in a request for a variance to WAC 173-160-420 as interpreted in the letter referenced above. 


\section{Geologic Considerations}

Subsurface geology exerts a fundamental control on fluid and contaminant migration. Consequently, an accurate understanding of subsurface geology is one cornerstone of any decision made to "ensure protection of the ground water resource and prevent contamination of that resource." Predeployment report review, coupled with analysis of specific geologic data collected during deployment, will allow identification of subsurface geologic features with a high degree of confidence.

\subsection{Site Geology}

Although locally quite variable, the general geology beneath each Hanford Site SST farm is generally well known and documented (Price and Fecht, 1976a through 1976l; Tallman et al., 1979, 1981; Caggiano and Goodwin, 1991; Lindsey and Law, 1993; Reidel et al., 1994; Lindsey et al., 1991, 1992, 1994a, 1994b). Typical general geologic conditions present beneath tank farms that influence fluid and contaminant migration, and therefore abandonment decisions, and that commonly can be identified in previously published reports include the:

- Geologic units present

- Extent of layers composed of very permeable sediment

- Presence of coarse and uncemented lithologies

- Nature and extent of fine-grained horizons (silt and clay) that block or inhibit downward migration of moisture and contaminants

How each of these geologic features influence grouting decisions for CP borings is discussed in the following subsections. 


\subsubsection{Geologic Units}

Geologic units beneath the Hanford Site are composed of sediment that ranges from well consolidated and cemented to completely unconsolidated and uncemented (Myers et al., 1979; Tallman et al., 1979, 1981; DOE, 1988; Reidel et al., 1992; Lindsey et al., 1994a, 1994b). The most consolidated and cemented units at Hanford-the sand and gravel of the Ringold Formation and the overlying calcium carbonate cemented silt, sand, and gravel of the Plio-Pleistocene unitare found only in the lower part of the unsaturated zone beneath the 200 West area. The most common unsaturated zone unit in the 200 West and East areas is the Hanford formation (Tallman: et al., 1979, 1981; DOE, 1988; Reidel et al., 1992; Lindsey et al., 1994a, 1994b). The Hanford formation lithologies generally are uncemented, only partially consolidated, and variably cohesive. Given these physical conditions, collapse and filling of the boring is likely, negating the need for grouting. The presence of the Hanford formation at any SST farm can be easily determined from existing reports, although identification of specific lithologies present and their susceptibility to collapse generally requires site-specific data.

\subsubsection{Consolidation and Cohesion}

In the Hanford formation the relative abundance of the main facies, gravel, sand, and silt, vary from tank farm to tank farm. Consolidation and cohesion are generally greater in silty deposits and less, or nonexistent, in sand- to gravel-dominated strata. Consequently, where fines dominate, borings are more likely to stay open following $\mathrm{CP}$ rod removal. In areas where unconsolidated coarser Hanford formation strata dominate, the likelihood of borehole collapse during abandonment is high. Collapse could occur immediately after rod removal as loose, noncohesive sediment particles are forced into the abandoned boring by gravity and lithostatic loading. Collapse may also occur after rod extraction as repeated wetting and drying of sediment at the borehole-sediment interface leads to weakening and collapse of the borehole wall.

At locations where more cohesive fines are dominant (versus those dominated by less cohesive sand and gravel), borings are more likely to remain open following rod extraction. This situation poses an actual or potential risk for groundwater contamination because an open boring can provide a pathway for fluid and contaminant migration under some conditions. If contamination is present, grouting is recommended to meet the intent of $90.48 \mathrm{RCW}$ and WAC 173-160. 
Acquisition of site-specific lithologic data (to be coupled with contamination data), which is readily gathered during $\mathrm{CP}$ deployment through calibrated resistance measurements, is required to differentiate lithologies and provide input for evaluating site conditions (e.g., consolidation and cohesion) relative to grouting decisions.

\subsubsection{Porosity and Permeability}

Naturally highly permeable Hanford formation gravel and sand dominate much of the unsaturated zone at Hanford (Connelly et al., 1992a, 1992b). Consequently, secondary porosity and permeability related to open, or partially open, CP borings in these lithologies will not significantly change porosity and permeability of the lithologies. In addition, the likelihood of a boring in these lithologies remaining open is low, because Hanford formation sand and gravel is almost completely uncemented and is readily susceptible to collapse in uncased borings. Grouting of a boring in these lithologies will likely have a negligible effect on limiting fluid and contaminant migration in such naturally permeable lithologies.

The converse will likely be true where low permeability silt and clay beds are present. An open $\mathrm{CP}$ boring in low permeability silt and clay strata (which do not readily collapse) can provide significant secondary permeability and form a conduit for contaminant migration under saturated, or nearly saturated, conditions. Grouting of borings in such strata may be desirable to eliminate this secondary permeability, seal impermeable layers penetrated by CP borings, and ensure protection of underlying groundwater.

Specific SST farm reports generally contain enough lithologic data to determine the dominance of basic facies types beneath an SST farm. However, detailed site-specific data generally are too sparse to allow identification of specific beds, horizons, or intervals that may require grouting. Such data will need to be collected from analysis of CP data during deployment.

\subsubsection{Field Verification}

Predeployment literature review will provide the information needed to understand basic site geologic conditions and provide a framework for interpreting the parameters discussed above. 
However, field verification of these parameters will be required prior to a final grouting decision. Field verification of subsurface conditions is readily attained using the $\mathrm{CP}$.

Initial CPT field deployment (e.g., cold deployment) will center on testing at sites where contaminant hazards do not exist. This testing is directly relevant to determining grouting requirements because it allows calibration of $\mathrm{CP}$ data to the Hanford Site geologic conditions discussed above. The CP method relies on a combination of penetration mechanics and a practical database to make semi-theoretical estimates of lithologies penetrated. Calibration penetrations made within well-documented materials of the type expected to be penetrated in later deployments provide the data needed to build the practical database. For a calibration test, spacing between $\mathrm{CP}$ borings and previously characterized drill holes should be kept as low as possible (within 10 feet). Samples retrieved from drilled boreholes and interpreted by laboratory or other relevant analysis establish control data necessary to calibrate $\mathrm{CP}$ responses and confidently interpret subsurface geology.

One example of a calibration approach is provided in Steedman (1997). A model such as the one described in that report will support grout decisions related to groundwater protection where risks exist. Additionally, this type of effort supports site characterization activities with quantitative characterization derived from $\mathrm{CP}$ resistance data. This approach will be facilitated, with minimal budget impact, if during cold testing $\mathrm{CP}$ calibration pushes are located near previously drilled boreholes from which lithology data has been collected.

\subsection{Perched Water and Subsurface Moisture}

Perched water is defined as unconfined groundwater separated from an underlying main body of groundwater by an unsaturated zone (AGI, 1976). The requirements of WAC 173-160-075 indicate perched water zones may need to be sealed to prevent cross-communication to the underlying aquifer and to ensure the protection of groundwater resources. Based on this guideline, identifying the presence and extent of perched water is very important to making borehole grouting decisions. 
Prior characterization and waste management experience at Hanford suggests that widespread perched water zones, while present, are rare (Rohay et al., 1993; Singleton and Lindsey, 1994; Lindsey et al., 1994a, 1994b). Perched water beneath much of the Hanford Site tends to be localized on impermeable strata that display many discontinuities related to erosional and depositional pinch outs and vertical truncations (Baker et al., 1991; Reidel et al., 1992; Lindsey et al., 1994b; Fecht et al., in preparation). Nevertheless, in cases where contamination is present (as discussed in Section 4.3), perched water may pose a potential threat to groundwater, which must be mitigated.

Subsurface interstitial moisture in the unsaturated zone does not have to be present in high enough quantities to reach saturation (forming a perched water zone) to pose a potential threat to underlying groundwater. Interstitial moisture in the unsaturated zone moves downward and laterally through the vadose zone in response to gravity and geologic heterogeneities. Generally, as subsurface moisture content increases, the moisture flux (or movement) increases, and contaminant migration can be enhanced. Open CP boreholes may provide preferred pathways if moisture fluxes are high enough.

Prior to deployment, the presence and extent of historical perched water and interstitial moisture may be estimated by examining records that describe the presence of water in the vadose zone borings, moisture data collected during previous investigations, and geophysical data. However, in order to meet the $90.48 \mathrm{RCW}$ requirement to protect groundwater quality, site-specific data will need to be collected if a boring is to remain ungrouted. The geologic analysis described in Section 4.1, coupled with borehole logging tools designed to identify moisture content, will provide the information needed to make a technically defensible grouting decision and ensure groundwater quality protection.

\subsection{Subsurface Contamination}

Given the nature of Hanford SST farms, subsurface contamination probably will be encountered in some CP borings. In order to make a technically defensible grouting decision and ensure groundwater protection, the nature of the contamination and the vadose zone geologic framework 
in which it exists must be determined. The main parts of the hydrogeologic framework are described in Section 4.1. Subsurface contamination considerations are described in this section.

Different radioactive and chemical contaminants move through the subsurface at different rates. Rates of migration depend on chemical and physical interactions between a given contaminant and the geologic framework in which it is found. Technically defensible grouting decisions made pursuant to the requirement to protect groundwater quality will require the identification of any contaminants present.

Sensors may be used to identify some contaminants potentially encountered during $C P$ deployment. Chemical analysis of discrete subsurface soil samples offers another method of identifying particular subsurface contaminants. If direct contaminant analyses cannot ascertain the nature of subsurface contamination and possible risk, if any, of groundwater contamination, an indirect assessment may provide defensible estimates of potential contaminant mobility and threats to groundwater quality. Such an assessment would combine contaminant estimates (gathered from tank inventories) with geology and moisture data collected during CP deployment to determine the probable extent of contamination and to constrain grouting decisions. 


\section{Operational Considerations}

Operational considerations related to CP deployment will be factored into grouting and borehole abandonment decisions. However, these operational considerations are subordinate to the regulatory guidance that requires protection of groundwater resources. Relevant operational issues discussed in this section relate to the deployment conditions, grout types, grout penetration into strata surrounding the boring, and CP boring spacing.

\subsection{Deployment}

Current HTI CPT deployment plans indicate that up to three penetrations or pushes will be undertaken at each point. The first push will emplace an instrumented multi-sensor probe (MSP). Because the MSP rod is almost completely filled with wiring for the MSP rod at the bottom of the rod string, it cannot be used to emplace grout. Consequently, a second, optional push will be made in the MSP boring after the MSP is removed to emplace a hollow rod for use in grouting the MSP boring. The third push will be 18 to 24 inches from the MSP boring to emplace a soil sampling probe (SSP), which will be retrieved to the surface using a wireline system. Following SSP retrieval, grout will be pumped down the hollow push rods as they are removed from the boring, thus sealing the hole. DBS\&A recommends this plan be modified as described below in order to facilitate data collection and grouting decisions.

The deployment plan recommended by DBS\&A begins with emplacing the MSP probe as originally planned. During MSP pushing, penetration resistance data will be collected, compared with calibration data, and used for lithologic interpretations. Contaminants will aiso be characterized using the MSP probe to the extent possible. Following completion of the MSP push, the CP platform will be indexed 18 to 24 inches away for the second, or SSP, push. With the SSP push, soli samples will be collected for contaminant characterization. In addition, once the soil samples are collected, the SSP rod will be hollow. A moisture logging tool will then be run within the hollow SSP rod to determine interstitial moisture content and the presence of perched water. The hollow SSP rod also offers the possibility of collecting other contaminant characterization data if tools are available. Once the moisture data, contaminant data, and lithologic data are collected, grouting decisions can be made, and the MSP and SSP rods 


\section{HNF-2048, Rev. 0}

DANIEL B. STEPHENS \& ASSOCIATES, INC.

ENVIRONMENTAL SCIENTISTS AND ENGINEEAS

extracted. If grouting is deemed advisable, the SSP hole will be grouted upon extraction and the MSP hole will be penetrated with a hollow rod to grout the boring.

"Re-penetration" assumes successful reoccupation of the initial MSP boring with the optional grouting push. This is important because the purpose of repenetration is to get grout into the MSP hole and seal it. As a practical matter, this is likely because the process of hydraulic driving will result in push rods following the path of least resistance through the subsurface. This path will tend to be the preexisting borehole. Furthermore, an experienced CP operator using the platform hydraulic readings to monitor penetration resistance can determine if $\mathrm{CP}$ rods are penetrating undisturbed strata in contrast to the initial boring or a collapsed boring. If the original boring cannot be reoccupied during the second push, because of collapse or rod deflection, an optimal grouting push will accomplish little in the way of effectively sealing the first boring and will not be required.

\subsection{Grout Type}

If deep grouting is required, the narrow inside diameter of hollow grouting rods (1.25 inches) argues against the use of dry grout material, such as bentonite crumbles or high viscosity liquid grout. These materials are susceptible to bridging and plugging of small diameter $\mathrm{CP}$ rods and tremie tubes. Bridging will prevent grout from reaching the base of the borehole and completely sealing it. However, these grouts may be adequate if the construction of a surface seal for the upper 5 to 15 feet of the boring is required. Successful, consistent placement of grout at depth will require the use of low viscosity liquid grout.

The decision to place a surface seal, to seal selected horizons, or to grout the entire boring, and therefore the selection of grout type, will be guided by site-specific hydrogeologic and contaminant conditions evaluated in light of Ecology regulations and rules.

\subsection{Grout Penetration}

The radius of grout penetration into strata surrounding the boring will be critical in the HTI project because the total number of CP probe pushes planned for each location will require several closely spaced separate penetrations (<24 inches apart), each collecting its own suite of data. 
If grout penetrates into the sampling field of an adjacent boring, either SSP or MSP, these samples will be compromised. Widespread accumulations of grout also may impact future sampling for yet to be determined waste storage and retrieval issues. The results of this exercise will then be used to decide if grouting will affect data acquisition objectives for nearby, closely spaced boreholes. If it is determined that it will, then grouting of closely spaced borings should be postponed (if Ecology guidance requires it) until all data acquisition objectives for closely spaced borings are achieved.

The deployment sequence proposed in Section 5.1 will eliminate the problem of grouting affecting adjacent borings because grouting is the final action taken prior to moving off a CP boring location. If the sequence cannot be followed, grout penetration into different geologic facies should be estimated, calculated, or directly measured as part of cold test deployment.

\subsection{Hole Spacing}

Hole spacing for the standard CPT measurements (resistance to penetration) is explicitly limited to "25 boring diameters" by the American Society for Testing and Materials, in ASTM D 3441, Standard Test Method for Deep, Quasi-Static, Cone and Friction-Cone Penetration Tests. This standard ensures the collection of data from material that has not been disturbed by strain prior to penetration. Based on planned deployment of 2-inch-outside-diameter (O.D.) rods, the ASTM standard for HTI's project is 50 inches. Although not directly relevant to grouting decisions, this standard will influence which $\mathrm{CP}$ penetrations will be used for lithologic data acquisition. However, this standard has no effect on the collection of data for chemical or contaminant analyses. 


\section{General Recommendations}

Preventing the spread of contamination known to occur beneath Hanford tank farms is the bottom line for abandonment of HTI's planned CP boring. HTI's CP emplaced, geotechnical test borings must be abandoned in such a manner to "ensure protection of the groundwater resource and prevent contamination of that resource." To do this, HTI has two options:

- Grout all borings, regardless of conditions (according to current Ecology guidance)

- Use technically defensible arguments to apply for a variance exempting $\mathrm{CP}$ borings from grouting where site conditions do not warrant the need to grout. Sections 4 and 5 discussed the issues that will need to be addressed if a variance is to be granted. These issues are summarized in Table 1 and in the remainder of this section.

Prior to cold deployment and prior to deployment to individual tank farms, the literature should be reviewed (as discussed in Section 4) to identify physical constraints likely to be present at deployment sites. During cold deployment, calibration data (as described in Section 4.1.4) should be collected and analyzed as a standard part of the investigation. Calibrated $\mathrm{CP}$ resistance data used to identify lithology can then be combined with known and estimated moisture, perched water, and contaminant data to evaluate probable threats of groundwater contamination. If this evaluation reveals that $\mathrm{HTI}$ cannot ensure groundwater protection without grouting, providing a basis for granting a variance, the borings should be grouted.

Under certain circumstances where grouting is required, site-specific data may indicate that grouting of the entire borehole is not needed. A variance requiring only limited subsurface grouting may be applicable to situations where:

- Contamination is restricted to only a few stratigraphic horizons in a given boring

- Only immobile contamination is found

- Perched water is absent and moisture content is low

- A boring is predominantly in geologic facies subject to rapid collapse after rod extraction 


$$
\text { HNF-2048, Rev. }
$$

DANIEL B. STEPHENS \& ASSOCIATES, INC.

ENVIRONMENTAL SCIENTISTS ANO ENGINEERS

Table 1. Factors That Influence Grouting Decisions

\begin{tabular}{|c|c|}
\hline Factor & Decision \\
\hline $\begin{array}{l}\text { Regulations (90.48 RCW } \\
\text { and WAC 173-160) }\end{array}$ & $\begin{array}{l}\text { Grouting required in lieu of a variance to ensure protection of } \\
\text { groundwater resource. Factors to be addressed in a request for variance } \\
\text { are listed below. }\end{array}$ \\
\hline Site geology & $\begin{array}{l}\text { No - If boring predominantly in collapsible sand and gravel } \\
Y^{2}{ }^{2} \text { - If cohesive silt comprises }>25 \% \text { of strata penetrated by boring, } \\
\text { except if layers laterally discontinuous }\end{array}$ \\
\hline $\begin{array}{l}\text { Perched water/soil } \\
\text { moisture }\end{array}$ & $\begin{array}{l}\text { No - If perched water not present or laterally discontinuous, or if there is } \\
\text { a low soil moisture flux } \\
\text { Yes }{ }^{a, b} \text { - If perched water widespread and/or contains contamination, or if } \\
\text { there is a high soil moisture flux }\end{array}$ \\
\hline $\begin{array}{l}\text { Subsurface } \\
\text { contamination }\end{array}$ & $\begin{array}{l}\text { No - If immobile } \\
\text { Yes } a, b, c, d \text { - If mobile }\end{array}$ \\
\hline $\begin{array}{l}\text { Multiple penetrations at } \\
\text { a single setup }\end{array}$ & $\begin{array}{l}\text { No - If no to all of above } \\
\text { Yes - If yes to any of above }\end{array}$ \\
\hline Dry/high viscosity grout & Surface seal only \\
\hline Liquid grout & $\begin{array}{l}\text { No - If no to all of above } \\
\text { Yes }^{\text {e }} \text { - If yes to any of above }\end{array}$ \\
\hline
\end{tabular}

a May attempt to seal selected fine-grained horizons that act as natural barriers to fluid and contaminant migration.

b Will default to yes decision to ensure groundwater protection if extent of perched water, soil moisture flux, or type of contamination cannot be characterized.

c Surface seal may be an alternative, especially if site dominated by collapsible strata.

May attempt to seal just-contaminated horizons, especially if site dominated by collapsible strata.

- If multiple, closely spaced sampling events planned (e.g., sampling events within the radius of penetration of grout from adjacent borings); may grout borings after all sampling completed.

In cases like these grouting may only be necessary to:

- Seal a contaminated stratigraphic horizon

- Place a surface seal to block movement of water into a partially open abandoned boring

- Fill stratigraphic intervals encountered in a boring that are less subject to collapse (finegrained dominated)

- Seal perched water horizons or layers where moisture content is high

An adequate understanding of subsurface geology and contaminant migration will support the decisions to grant a full or partial variance to CP boring grouting and still achieve groundwater protection. A flow chart showing the grout decision process is shown in Figure 1. 


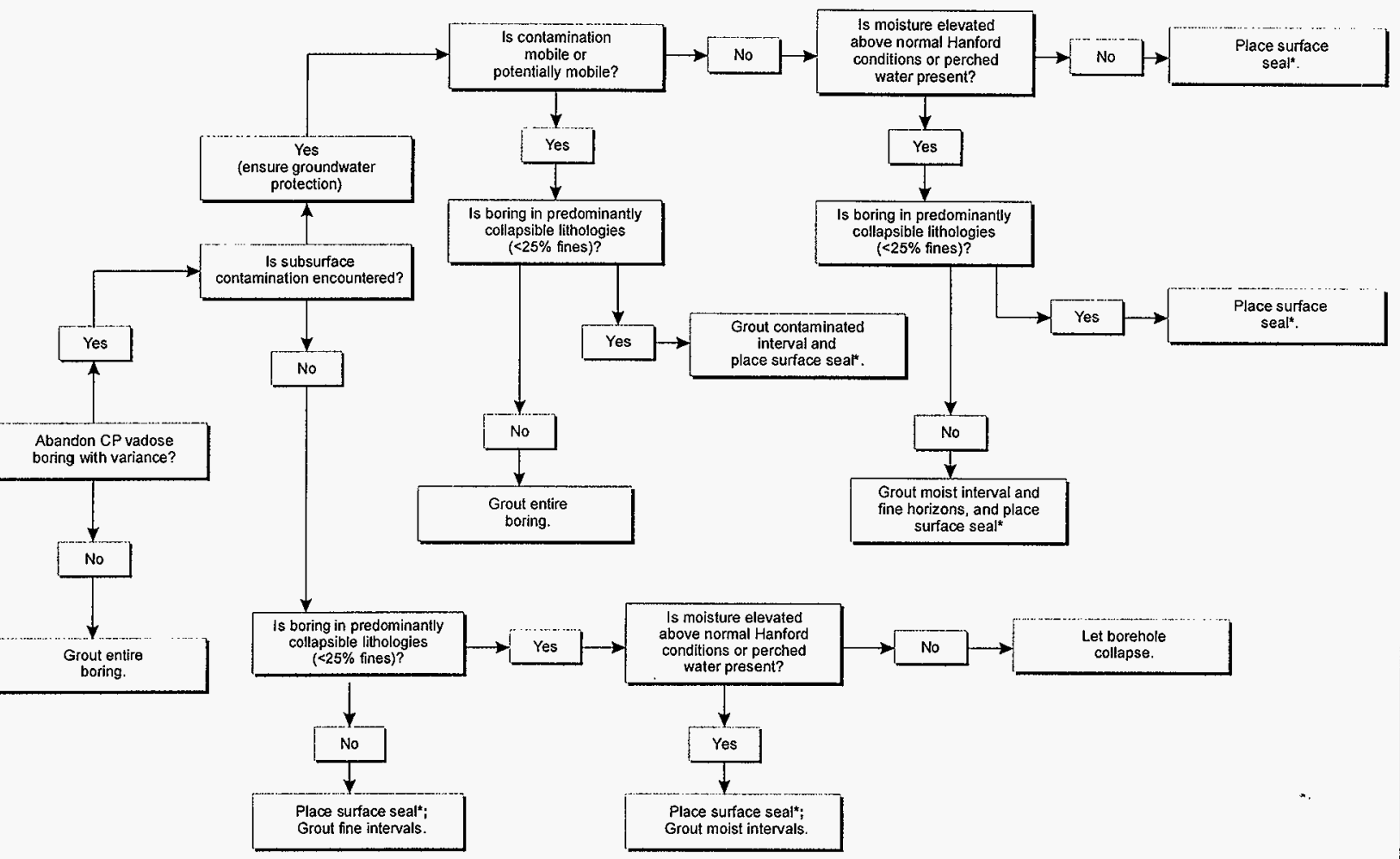

"Place surface seal if borehole does not visibly collapse following CP rod extraction. 


\section{Specific Recommendations for the 241-AX Tank Farm}

This section addresses the issues raised in previous sections for predeployment CP planning relative to the $241-A X$ tank farm.

\subsection{Geology of the 241-AX Tank Farm}

The vadose zone beneath the 241-AX tank farm is found almost entirely within the Hanford formation (Figures 2 and 3), although the lowermost few meters of the vadose zone extend downward into the Ringold Formation. Backfill forms the uppermost part of the vadose zone. The following discussion of 241-AX tank farm vadose zone geology is based on data and interpretations in Price and Fecht (1976a through 1976m), Caggiano and Goodwin (1991), Lindsey and Law (1993), borehole logs from the site, grain size data in the ROCSAN database, and analysis of geologic features found elsewhere that are interpreted to be analogous to those at the tank farm.

\subsubsection{Backfill}

Backfill consists of slightly pebbly to slightly silty coarse to fine sand (Price and Fecht, 1976a through $1976 \mathrm{~m}$ ) removed from the original excavation and later returned during tank construction. Available information suggests that the backfill was not compacted to set specifications, although it was returned to the excavation in lifts, resulting in varying degrees of compaction because of day-to-day construction activity. Backfill ranges from 0 to $17 \mathrm{~m}$ ( 0 to 55.8 feet) thick at the 241-AX tank farm.

\subsubsection{Hanford Unit H1}

The uppermost 0 to $15 \mathrm{~m}$ ( 0 to 50 feet) beneath the base of the backfill and tank farm consists of a westward thinning sequence of slightly silty, pebbly, very coarse to coarse sand and sandy, fine to very fine pebble gravel to pebbly very coarse sand (Price and Fecht, 1976a through $1976 \mathrm{~m})$, assigned to Unit $\mathrm{H} 1$. These strata are interpreted to consist of interbedded sand and gravel facies, with gravel beds generally thinning to the west and south. This interval is divided 
(A) North

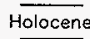

Pleistocene

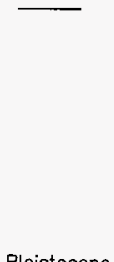

PlioceneMiocene

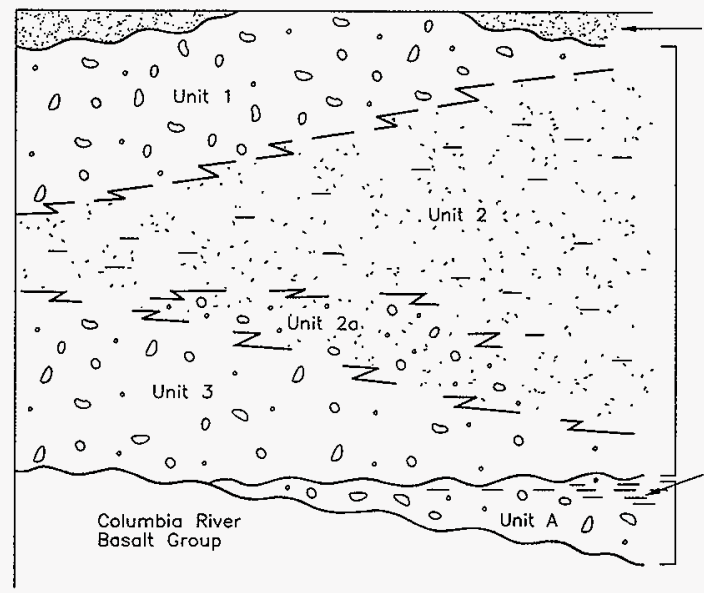

South

Holocene Surficiol

Deposits

Hanford

formation

Lower

Mud Unit

Ringold Formation Member of Wooded Island

Explanation

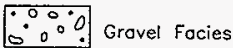

Source: Hanford drowing H96010075.8 


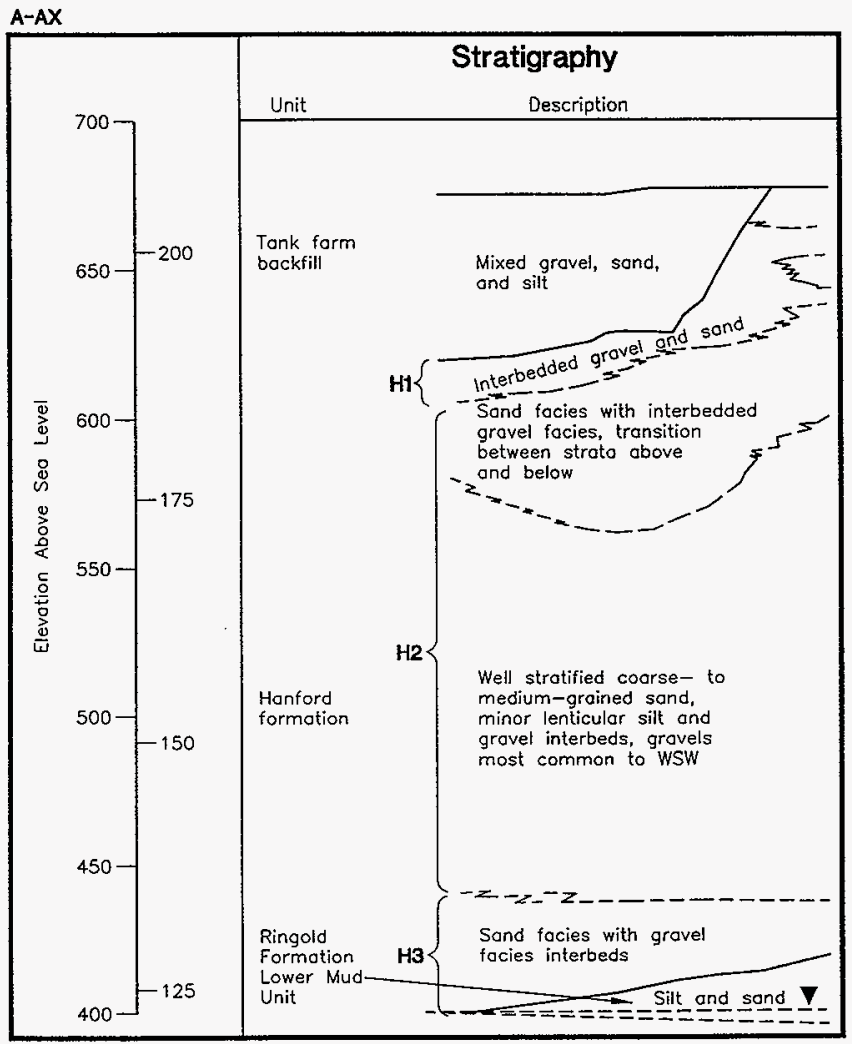

Source: Honforo drawing H96010075.2 
into an upper, laterally discontinuous, sand-rich interval, designated $\mathrm{H} \uparrow \mathrm{A}$, and a lower, more gravel-rich interval, designated $H 1$. $H 1$ and $H 1 A$ interfinger. Beneath the tank farm the $H 1 / H 1 A$ contact is 75 to 80 feet below ground surface.

Throughout both Units $\mathrm{H} 1$ and $\mathrm{H} 1 \mathrm{~A}$, bedding is typically laterally discontinuous, with interfingering sand- and gravel-rich horizons forming a complex series of tabular and wedge-shaped lenses. Grain size data, borehole log descriptions, and excavations such as those described by Goldstrand (1984) suggest that pebbles ( 2 to $64 \mathrm{~mm}$ ) dominate the gravel fraction. Total gravel content varies from 10 to 51 weight percent in sampies from $\mathrm{H} 1$ and $\mathrm{H} 1 \mathrm{~A}$.

There is no direct evidence of muddy horizons beneath the 241-AX tank farm. However, outcrops of sand-dominated and gravel-dominated facies deposits like those underlying the tank farm do occasionally contain mud lenses and mud interbeds. Samples with mud content in excess of 20 weight percent also suggest the likely presence of mud beds.

\subsubsection{Hanford Unit $\mathrm{H} 2$}

Unit $\mathrm{H} 1$ is underlain by 30 to $45 \mathrm{~m}$ (100 to 150 feet) of slightly silty, very coarse to medium sand and very coarse to medium sand (Price and Fecht, 1976a through 1976m), assigned to Unit $\mathrm{H} 2$. Based on these descriptions, examination of borehole geologic logs, and characteristics found in outcrops of analogous strata, the lithologies composing Unit $\mathrm{H} 2$ are interpreted to be dominated by well-stratified sand typical of the sand-dominated facies. Although not explicitly described in borehole logs at the 241-AX tank farm, the sandy strata forming Unit $\mathrm{H} 2$ are inferred to contain thin ( $<0.5 \mathrm{~m}[<1.6$ feet]), lenticular silt interbeds. This interpretation is based on the presence of mud-rich (>20 weight percent) samples in the ROCSAN database, borehole geologic log descriptions from similar strata at other locations (Lindsey et al., 1992, 1994b), cross sections of the nearby 241-A tank farm showing muddy horizons (Caggiano and Goodwin, 1991), and examination of analogous outcrops (Reidel et al., 1992; Lindsey et al., 1994a). Borehole logs, coupled with grain size data in ROCSAN, indicate the presence of graveliy sand intervals as much as $7 \mathrm{~m}$ (23 feet) thick, and a downward coarsening into Unit H3. Several gravelly intervals may be laterally persistent beneath the entire site. The top of Unit $\mathrm{H} 2$ is located 30 to $32.5 \mathrm{~m}$ (100 to 115 feet) below the surface of the tank farm. 


\subsubsection{Hanford Unit H3}

The lower part of the Hanford formation consists of an interstratified sequence of sand- and gravel-dominated facies called Unit $\mathrm{H} 3$. Only three borings at the 241-AX tank farm go deep enough to reach Unit $\mathrm{H} 3$; consequently, physical characteristics for this unit are largely inferred. The limited information available suggests this unit has bedding geometries and mud content similar to those found in Unit $\mathrm{H} 1$. The number, thickness, and lateral extent of individual gravel beds may be less in Unit $\mathrm{H} 3$ than in Unit H1. The top of Unit $\mathrm{H} 3$ is found approximately $70 \mathrm{~m}$ (220 feet) below the surface and, consequently, is beyond the range of proposed CP borings.

\subsubsection{Ringold Formation}

The Ringold Formation is found at the base of the vadose zone section at the 241-AX tank farm. Because the top of the Ringold is approximately $90 \mathrm{~m}$ (260 feet) below the surface, it will not be reached by any proposed CP boring and is not described further here.

\subsection{Perched Water and Moisture}

As discussed in the previous section, vadose zone strata beneath the 241-AX tank farm consist predominantly of Hanford formation sand and gravel facies. These facies contain only limited fine interbeds, which are usually not laterally continuous. Silt- and sand-filled clastic dikes also are common in this facies, further limiting lateral stratigraphic continuity of potential perched water zones. In addition, clastic dikes may provide vertical pathways for fluid and contaminant migration (Fecht et al., in preparation). These factors suggest that widespread perched water is probably not present. As to the extent of subsurface moisture, we are unable to draw any conclusions at this time because we are not aware of any 241-AX tank farm-specific moisture data. However, the relative lack of fines inferred for the 241-AX tank farm suggests that soil moisture should migrate downward with little impedance. 


\subsection{Subsurface Contamination}

Tanks $A X-102$ and $A X-104$ have leaked approximately 11,000 gallons since the 241-AX tank farm was constructed in 1965. Consequently, subsurface contamination will in all likelihood be encountered in some of the borings to be emplaced. This contamination may be disseminated throughout the dominant sand facies found beneath the tank farm, concentrated on relatively rare, lenticular silt interbeds and clastic dikes or a combination of both. The nature and distribution of subsurface contamination needs to be determined so it can be factored into grouting decisions.

\subsection{Deployment Recommendations for the 241-AX Tank Farm}

Based on the geologic conditions currently known or inferred to be present, we recommend that a variance to widespread grouting be requested for the following reasons:

- The dominance of uncemented, unconsolidated, and uncompacted sand facies beneath this tank farm leads to the conclusion that boreholes will readily collapse following $\mathrm{CP}$ rod removal. Under such conditions it may become difficult to consistently reoccupy MSP borings to seal them.

- Grouting of these collapsed, or partially collapsed, boreholes in highly permeable sand facies probably will not significantly reduce moisture and contaminant migration characteristics of such deposits. Partially opened borings will not readily increase the primary flow pathways through such high-permeability deposits.

- The probability of intersecting perched water and/or zones of elevated subsurface moisture that could pose a threat to groundwater quality is extremely low, given coarse lithologies, small leak history, and depth to water.

- Because the strata underlying the tank farm are very coarse and highly permeable, there is a high probability that low viscosity grout will penetrate far enough into strata surrounding borings to negatively impact subsequent sampling in boreholes as closely spaced as 12 inches. 


$$
\text { HNF }-2048, \text { Rev. } 0
$$

DANIEL B. STEPHENS \& ASSOCIATES, INC.

ENVIRONMENTAL SCIENTISTS AND ENGINEERS

Where a potential threat to groundwater quality is found to exist at the 241-AX tank farm, we recommend that the following conditions be attached to a variance to ensure groundwater protection, given the physical conditions currently known to occur at the tank farm.

- Selective grouting of contaminated intervals detected during MSP deployment (if boring can be successfully reoccupied)

- Grouting of occasional, fine-grained strata where perched water could potentially accumulate or contamination concentrate

- Grouting of intervals where elevated moisture content is found

- Placement of surface seals in borings that stand open after rod removal to a depth of 5 to 15 feet to ensure that surface water from snow meit, rainfall, or industrial discharges cannot easily flow down partially open borings

All but the final of these conditions require the collection of site-specific data. 


$$
\text { HNF-2048, Rev. } 0
$$

\section{References}

American Geological Institute. 1976. Dictionary of Geological Terms, Revised Edition. Anchor Press/Doubleday Books, Garden City, New York.

Baker, V.R., B.N. Bjornstad, A.J. Busacca, K.R. Fecht, E.P. Kiver, U.L. Moody, J.G. Rigby, D.F. Stradling, and A.M. Tallman. 1991. Quaternary Geology of the Columbia Plateau, in Quaternary Nonglacial Geology; Conterminous United States, R.B. Morrison (ed.), The Geology of North America, Volume K-2, Geological Society of America, Boulder, Colorado. p. 215-250.

Black, R.F. 1979. Clastic Dikes of the Pasco Basin, Southeastern Washington. RHO-BW!-C-64. Rockwell Hanford Operations, Richland, Washington.

Caggiano, J.A. and S.M. Goodwin. 1991. Interim Status Groundwater Monitoring Plan for the Single Shell Tank Farms. WHC-SD-EN-AP-012. Westinghouse Hanford Company, Richland, Washington.

Connelly, M.P., J.V. Borghese, C.D. Delaney, B.H. Ford, J.W. Lindberg, and S.J. Trent. $1992 a$. Hydrogeologic Model for the 200 East Groundwater Aggregate Area. WHC-SD-EN-TI-019, Rev. 0 . Westinghouse Hanford Company, Richland, Washington.

Connelly, M.P., B.H. Ford, and J.V. Borghese. 1992b. Hydrogeologic Model for the 200 West Groundwater Aggregate Area. WHC-SD-EN-T1-014. Westinghouse Hanford Company, Richland, Washington.

Fecht, K.R., K.A. Lindsey, B.N. Bjornstad, D.G. Horton, and S.P. Reidel. In preparation. An Atlas of Clastic Injection Dikes of the Pasco Basin and Vicinity. BHI-01103. Bechtel Hanford, Inc., Richland, Washington.

Lindsey, K.A. and A. Law. 1993. Geohydrologic Setting, Flow, and Transport Parameters for the Single Shell Tank Farms. Internal Memo 81231-93-060. Westinghouse Hanford Company, Richland, Washington.

Lindsey, K.A., M.P. Connelly, and B.N. Bjornstad. 1991. Geologic Setting of the 200 West Area: An Update. WHC-SD-EN-TI-008. Westinghouse Hanford Company, Richland, Washington.

Lindsey, K.A., B.N. Bjornstad, J.W. Lindberg, and K.M. Hoffman. 1992. Geologic Setting of the 200 East Area: An Update. WHC-SD-EN-TI-012. Westinghouse Hanford Company, Richland, Washington.

Lindsey, K.A., S.P. Reidel, K.R. Fecht, J.L. Slate, A.G. Law, and A.M. Tallman. $1994 a$. Geohydrologic Setting of the Hanford Site, South-Central Washington. In Geologic Field Trips in the Pacific Northwest, Volume 1. D.A. Swanson and R.A. Haugerud (eds.). University of Washington Department of Geological Sciences, Seattle, Washington. pp. 1C 1-16. 
HNF-2048, Rev. 0

DANIEL B. STEPHENS \& ASSOCIATES, INC.

ENVIRONMENTAL SCIENTISTS AND ENGINEERS

Lindsey, K.A., J.L. Slate, G.K. Jaeger, K.J. Swett, and R.B. Swett. 1994b. Geologic Setting of the Low-Level Burial Grounds. WHC-SD-EN-TI-290. Westinghouse Hanford Company, Richland, Washington.

Myers, C. W., S.M. Price, J.A. Caggiano, M.P. Cochran, W.J. Czimer, N.J. Davidson, R.C. Edwards, K.R. Fecht, G.E. Holmes, M.G. Jones, J.R. Kunk, R.D. Landon, R.K. Ledgerwood, J.T. Lillie, P.E. Long, T.H. Mitchell, E.H. Price, S.P. Reidel, and A.M. Tallman. 1979. Geologic Studies of the Columbia Plateau: A Status Report. RHO-BWI-ST-4. Rockwell Hanford Operations, Richland, Washington.

Price, W.H. and K.R. Fecht. 1976a. Geology of the 241-A Tank Farm. ARH-LD-127. Atlantic Richfield Hanford Company, Richland, Washington.

Price, W.H. and K.R. Fecht. 1976b. Geology of the 241-AX Tank Farm. ARH-LD-128. Atlantic Richfield Hanford Company, Richland, Washington.

Price, W.H. and K.R. Fecht. 1976c. Geology of the 241-B Tank Farm. ARH-LD-129. Atlantic Richfield Hanford Company, Richland, Washington.

Price, W.H. and K.R. Fecht. 1976d. Geology of the 241-BX Tank Farm. ARH-LD-130. Atlantic Richfield Hanford Company, Richland, Washington.

Price, W.H. and K.R. Fecht. 1976e. Geology of the 241-BY Tank Farm. ARH-LD-131. Atlantic Richfield Hanford Company, Richland, Washington.

Price, W.H. and K.R. Fecht. 1976f. Geology of the 241-C Tank Farm. ARH-LD-132. Atlantic Richtield Hanford Company, Richland, Washington.

Price, W.H. and K.R. Fecht. 1976g. Geology of the 241-S Tank Farm. ARH-LD-133. Atlantic Richfield Hantord Company, Richland, Washington.

Price, W.H. and K.R. Fecht. 1976h. Geology of the 241-SX Tank Farm. ARH-LD-134. Atlantic Richfield Hanford Company, Richland, Washington.

Price, W.H. and K.R. Fecht. 1976i. Geology of the 241-SY Tank Farm. ARH-LD-139. Atlantic Richfield Hanford Company, Richland, Washington.

Price, W.H. and K.R. Fecht. 1976j. Geology of the 241-T Tank Farm. ARH-LD-135. Atlantic Richfield Hanford Company, Richland, Washington.

Price, W.H. and K.R. Fecht. 1976k. Geology of the 241-TX Tank Farm. ARH-LD-136. Atlantic Richfield Hanford Company, Richland, Washington.

Price, W.H. and K.R. Fecht. 1976I. Geology of the 241-TY Tank Farm. ARH-LD-137. Atlantic Richfield Hanford Company, Richland, Washington.

Price, W.H. and K.R. Fecht. $1976 \mathrm{~m}$. Geology of the 241-U Tank Farm. ARH-LD-138. Atlantic Richfield Hanford Company, Richland, Washington. 
Reidel, S.P., K.A. Lindsey, and K.R. Fecht. 1992. Field Trip Guide to the Hanford Site. WHC-MR0391. Westinghouse Hanford Company, Richland, Washington.

Reidel, S.P., N.P. Campbell, K.R. Fecht, and K.A. Lindsey. 1994. Late Cenozoic Structure and Stratigraphy of South-Central Washington. In Regional Geology of Washington State. R. Lasmanis and E.S. Cheney (convenors). Washington Division of Geology and Earth Resources Bulletin 80, pp. 159-180.

Rohay, V.J., K.J. Swett, V.G. Johnson, G.V. Last, L.A. Lanigan, and L.A. Doremus. 1993. Characterization Status Report and Data Package for the Carbon Tetrachloride Site. WHCSD-EN-T1-202. Westinghouse Hanford Company, Richland, Washington.

Sara, M.N. 1994. Standard Handbook for Solid and Hazardous Waste Facility Assessments. Lewis Publishers, Boca Raton, Florida.

Singleton, K.M. and K.A. Lindsey. 1994. Groundwater Impact Assessment Report for the 216-U-14 Ditch. WHC-EP-0698. Westinghouse Hanford Company, Richland, Washington.

Steedman, D.W. 1997. Cone Penetrometer Testing and Textural Modeling of Copper Mill Tailings, in Proceedings of the Fourth Annual International Conference on Tailings and Mine Waste ' 97 , Fort Collins, Colorado.

Tallman, A.M., K.R. Fecht, M.C. Marratt, and G.V. Last. 1979. Geology of the Separations Areas, Hanford Site, South-Central Washington. RHO-ST-23. Rockwell Hanford Operations, Richland, Washington.

Tallman, A.M., J.T. Lillie, and K.R. Fecht. 1981. Suprabasalt Sediments of the Cold Creek Syncline Area, in Subsurface Geology of the Cold Creek Syncline. C.W. Myers and S.M. Price. RHO-BWI-ST-14. Rockwell Hanford Operations, Richland, Washington.

U.S. Department of Energy (DOE). 1988. Consultation Draft Site Characterization Plan. DOE/RW-0164, Volumes 1-9. Office of Civilian Radioactive Waste Management, Washington, D.C. 